\title{
Young EFL Learners' Processing of Phrasal Verbs: An Experimental Approach
}

\author{
Trisevgeni Liontou ${ }^{1}$ \\ ${ }^{1}$ Department of English Language \& Literature, National \& Kapodistrian University, Athens, Greece \\ Correspondence: Trisevgeni Liontou, Department of English Language \& Literature, National \& Kapodistrian \\ University, Philosophiki Campus, Zografou 157 84, Greece. E-mail: tliontou@enl.uoa.gr
}

Received: March 29, 2018 Accepted: May 1, 2018 Online Published: May 5, 2018

doi:10.5539/ijel.v8n5p1 URL: https://doi.org/10.5539/ijel.v8n5p1

\begin{abstract}
Research has shown that EFL learners face specific difficulties when processing phrasal verbs, mainly due to the fact that identical or similar expressions rarely exist in their mother tongue. Though some studies on second language acquisition have explored the development of figurative language competence and the strategies employed for the interpretation of phrasal verbs, limited research based information is available as regards the relationship between such a processing and learners' reading comprehension performance according to their level of English language competence. This paper reports on a one-year study that aimed at investigating the development of young learners' reading competence in relation to comprehending phrasal verbs. A total of 50 young EFL students aged 9 to 12 years old took part in the study. The findings could provide practical guidance to EFL instructors, material developers and test designers with regard to the type of reading comprehension difficulties EFL learners face when exposed to phrasal verbs while learning English as a Foreign Language.
\end{abstract}

Keywords: phrasal verbs, young EFL learners, material design, reading comprehension, vocabulary acquisition

\section{Introduction}

Along with idioms, phrasal verbs, that is, any verb and particle combination that function as one lexical and grammatical unit (Celce-Murcia \& Larsen-Freeman, 1999, p. 265; Crutchley, 2007, p. 204; Dempsey et al., 2007, p. 217; Dixon, 1982, p. 1; Kilby, 1984, p. 99; Koprowski, 2005, p. 323; Palmer, 1968, p. 180; Quirk et al., 1985, p. 1150), can pose additional difficulties to L2 learners, given that such verb phrases look nearly the same and the meaning of each one is not always apparent from its parts but has to be learnt by heart (Darwin \& Gray, 1999, p. 65; Kovecses \& Szabó, 1996, p. 326; Liu, 2003, p. 678; Quirk et al., 1985, p. 1152; Rodríguez-Puente, 2012, p. 72; Side, 1990, p. 144). In fact, many researchers believe that interpreting phrasal verbs is both linguistically and cognitively demanding for most EFL users (Celce-Murcia \& Larsen-Freeman, 1999, p. 425; Darwin \& Gray, 1999, p. 66; Gardner \& Davies, 2007, p. 340; Kao, 2001, p. 196; Liao \& Fukuya, 2004, p. 193), while using them in everyday written and oral communication is a strong indicator of language fluency (Coady, 1997, p. 282; Cornell, 1985, p. 269; Gardner \& Davies, 2007, p. 339; Nassaji \& Tian, 2010, p. 402). As Dagut and Laufer (1985, p. 78) showed in their study with Hebrew-speaking intermediate EFL learners and later Laufer and Eliasson (1993, p. 44) with advanced learners of English in Sweden, phrasal verbs often lead to learners' message misinterpretation and purposeful avoidance of such constructions by using standalone verbs with a straightforward meaning. However, such a practice only aggravates the problem, since it prevents learning and causes unnatural, prefabricated speech. Continuing the work of Dagut and Laufer and using the same forms of elicitation tests, Hulstijn and Marchena (1989, p. 241) showed that Dutch learners of English were prone to misinterpreting or avoiding phrasal verbs, especially figurative ones, even though similar structures did exist in their mother tongue. In fact, the $75 \mathrm{EFL}$ users that took part in their experiment exhibited an inclination towards using one-word verbs with general, multi-purpose meanings instead of phrasal verbs with specific and sometimes even idiomatic meaning (ibid, $p$. 246). As the researchers explained such a strategy might have played a causal role in the avoidance behaviour of the Hebrew learners observed earlier by Dagut and Laufer (ibid, p. 251). More recently, Liao and Fukuya also investigated the avoidance of English phrasal verbs by 85 Chinese learners of intermediate and advanced level and, similarly to Hulstijn and Marchena, found that both advanced and intermediate EFL users tended to refrain from using phrasal verbs, with intermediate learners showing even a higher preference for one-word equivalents (2002, p. 91). It should be noted that all four studies mentioned above have reached similar conclusions with regard to the 
effect the semantic nature of phrasal verbs had on learners' overall avoidance, since all participants tended to use straightforward phrasal verbs significantly more often than idiomatic ones in a variety of recognition and production tasks, but as they proceeded in their language competence this attitude diminished and usage of phrasal verbs approached that of native speakers. As the brief literature review on phrasal verbs has shown, most empirical studies to date have been conducted in laboratory settings, reflecting the strong psycholinguistic tradition in research on idioms with native speakers. Despite innovations in presenting phrasal verbs to learners, it seems that we are still at an initial stage of understanding their acquisition by non-native speakers and the effect the presence of the former may have on the reading comprehension performance of the latter, especially with connection to their level of language competence. Given the inherent difficulty of phrasal verbs and the impact their occurrence in reading texts can have on overall comprehension, the present study aimed to to fill this void and further add to our present state of knowledge on the processing of phrasal verbs by non-native learners by exploring their relationship with both perceived text difficulty and actual exam performance of young Greek-speaking EFL learners.

\section{Method}

The following research questions form part of the present study:

Research Question 1: Does contextual support have an impact on young EFL learners' performance when responding to specific reading comprehension questions that demand the interpretation of specific phrasal verbs?

Research Question 2: To what extent and in what ways are successful young EFL readers differentiated from less successful ones in terms of their awareness of phrasal verbs while completing a specific set of reading comprehension questions?

Participants had all been taught English as a Foreign Language as a compulsory school subject for a minimum of 4 years before taking part in the study. Signed forms of consent from parents for the involvement of all students in the project were collected. Their language proficiency level (B1) was diagnosed through a calibrated English language test (Cambridge Preliminary English Test-PET). A standardized multiple-choice reading test was used to investigate the impact, if any, of phrasal verbs on EFL students' reading skills. The test consisted of four texts with five multiple-choice reading-comprehension questions per text and was administered to all participants at the beginning of the course. Two of the texts contained 10 phrasal verbs with contextual support to deduce pertinent meaning whereas the remaining two texts included 10 phrasal verbs with no contextual support so no additional information was provided to facilitate interpretation (see examples in Appendix A). A parallel version of the same test was used to assess reading competence upon completion of the course. A total of 40 reading comprehension questions per student and 2,000 for the whole group of participants were collected. Data coding consisted in assigning a code number to each correct/ incorrect item. Frequency distributions were then calculated. Finally, data were subjected to further statistical analysis using IBM SPSS 20.0 statistical package. As far as reading comprehension performance is concerned, the mean task scores per text of the 50 EFL learners were also estimated. These mean scores, related to the specific multiple-choice reading comprehension questions included in each set of analysed texts, revealed significant relationships between mean reading performance before and after instruction.

\section{Results}

Data analysis of the scores obtained through achievement tests was based on a total of 2000 multiple-choice reading comprehension questions from the pre- achievement test and 2000 questions from the post- achievement test. Results indicated that young EFL participants' reading performance was significantly higher when context cues facilitated the interpretation of specific phrasal verbs, whereas standalone phrasal verbs were the hardest for participants to process $(\mathrm{t}=3.442, \mathrm{df}=48, \mathrm{p}=0.011)$. Moreover, in order to compare the mean reading performance of high and low-performers in the pre-test and post-test, a set of independent sample t-tests were carried out. This analysis showed that highly competent learners performed significantly better than their lower-level counterparts $\mathrm{did}$, regardless of the presence of more or less contextual information in a text $(\mathrm{t}=2.884, \mathrm{df}=48, \mathrm{p}=0.008)$. This finding could be an indication that contextualised information might facilitate the interpretation of figurative language by offering the necessary semantic information for learners to deduce pertinent meaning only when their overall language competence makes it possible to process text as a whole rather than getting stuck when encountering unfamiliar vocabulary, including phrasal verbs.

\section{Discussion}

The results of the present study showed that phrasal verbs similar to mother tongue equivalents were the easiest for EFL learners with a B1 level of language competence to comprehend, especially those with a verb and 
preposition that reveals direction. This could be attributed to the fact that the meaning of such word chunks lies on the actual verb while the preposition maintains its literal meaning. This finding comes in accord with Celce-Murcia and Larsen-Freeman (1999) who also argued that this specific category of phrasal verbs does not seem to be difficult for EFL learners to process and even include in their written or oral communication. Although test results varied greatly from subject to subject, participants comprehended and produced more easily those phrasal verbs that were frequently used in their everyday speech, had simple structure and literal meaning of each particle (i.e. verb and preposition) remained unaltered after their combined presence. Furthermore, contextualizing language and especially as regards semi-transparent or aspectual phrasal verbs proved to have a significant impact on participants' processing of relevant text information. This could be due to the fact that the meaning of these word chunks is not completely literal neither highly idiomatic but EFL learners might find it difficult to assign specific particles to verb sequences since these particles cannot be used in a random way (Celce-Murcia, 1999). Therefore, providing sufficient supportive contextual information could have a beneficial effect on the overall language learning process.

Having said that, foreign language learners' overall attitude to avoid using phrasal verbs could relate to the degrees of lexical similarity between the two languages. The present research showed that participants, regardless of their level of language competence, had greater difficulty deducing the meaning of idiomatic or non- transparent phrasal verbs, i.e. those verb and particle combinations in which the particle activates a metaphorical sense that cannot be inferred by the meaning of each part in isolation. Given the importance of phrasal verbs in the context of learning English as a foreign language and the inherent difficulties EFL learners face when exposed to them, additional effort should be made to develop effective teaching practices through our in-depth understanding of the processes involved in processing and interpreting phrasal verbs. Such knowledge can help EFL teachers and material developers towards the creation of a more comprehensive curriculum that would cover both literal and figurative language use in real-life written and spoken discourse.

To conclude, more studies are needed to explore the effect a variety of text genres can have on enhancing young language learners' processing of phrasal verbs along with investigating the combination of strategies employed throughout the process. It would also be interesting for future studies to examine, following a corpus-based approach, the presence of specific phrasal verbs in Greek EFL learners written and oral discourse.

\section{References}

Agnieszka E., \& Bock, K. (2009). Lexical or syntactic control of sentence formulation? Structural generalizations from idiom production. Cognitive Psychology, 58(1), 68-101. https://doi.org/10.1016/j.cogpsych.2008.05.002

Biber, D., Johansson, S., Leech, G., Conrad, S., \& Finegan, E. (1999). Longman Grammar of Spoken and Written English. Harlow: Longman.

Boas, H. (2013). Cognitive construction grammar. In T. Hoffmann \& G. Trousdale (Eds.), The Oxford handbook of construction grammar (pp. 233-254). Oxford: Oxford University Press.

Brinton, L. (1988). The Development of English Aspectual Systems. Cambridge: Cambridge University Press.

Cappelle, B., Shtyrov, Y., \& Pulvermüller, F. (2010). Heating up or cooling up the brain? MEG evidence that phrasal verbs are lexical units. Brain and Language, 115(3), 189-201. https://doi.org/10.1016/j.bandl.2010.09.004

Celce-Murcia, M., \& Larsen-Freeman, D. (1999). The grammar book. An ESL/EFL teacher's course. Boston: Heinle \& Henle.

Croft, W. (2001). Radical construction grammar. Syntactic theory in typological perspective. Oxford: Oxford University Press. https://doi.org/10.1093/acprof:oso/9780198299554.001.0001

Dagut, M., \& Laufer, B. (1985). Avoidance of Phrasal Verbs-A Case for Contrastive Analysis. Studies in Second Language Acquisition, 7(1), 73-79. https://doi.org/10.1017/S0272263100005167

Diessel, H., \& Tomasello, M. (2005). Particle placement in early child language: A multifactorial analysis. Corpus Linguistics and Linguistic Theory, 1(1), 89-112. https://doi.org/10.1515/cllt.2005.1.1.89

Dirven, R. (2001). English phrasal verbs: Theory and didactic application. In M. Pütz, S. Niemeier, \& R. Dirven (Eds.), Applied cognitive linguistics II: Language pedagogy (pp. 3-27). Berlin and New York: Mouton de Gruyter. https://doi.org/10.1515/9783110866254.3

Ellis, N. (2013). Construction grammar and second language acquisition. In T. Hoffmann \& G. Trousdale (Eds.), The Oxford handbook of construction grammar (pp. 365-378). Oxford: Oxford University Press. 
Ellis, R. (1986). Understanding second language acquisition. Oxford: Oxford University Press.

Gardy, M. (1970). Syntax and Semantics of the English Verb Phrase. Paris: Mouton. https://doi.org/10.1515/9783110909050

Gorbet, F. (1979). To Err is Human: Error Analysis and Child Language Acquisition. Journal of ELT, XXXIV, 22-28. https://doi.org/10.1093/elt/34.1.22

Hageman, L., \& Guerón, J. (1999). English Grammar: a Generative Perspective. Oxford: Blackwell.

Hatch, E. M. (1983). Psycholinguistics: A second language perspective. Rowley, MA: Newbury House.

Hulstijn, J., \& Marchena, E. (1989). Avoidance: Grammatical or semantic causes? Studies in Second Language Acquisition, 11(3), 241-255. https://doi.org/10.1017/S0272263100008123

Kamimoto, T., Shimura, A., \& Kellerman, E. (1992). A second language classic reconsidered-The case of

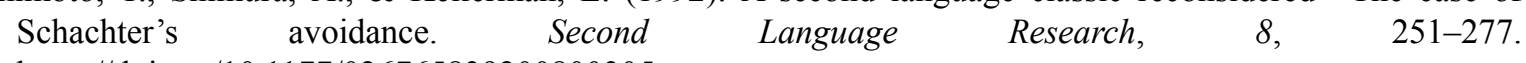
https://doi.org/10.1177/026765839200800305

Kleinmann, H. (1977). Avoidance Behavior in Adult Second Language Acquisition. Language Learning, 27(1), 93-107. https://doi.org/10.1111/j.1467-1770.1977.tb00294.x

Kurtyka, A. (2001). Teaching English phrasal verbs: A cognitive approach. In M. Pütz, S. Niemeier, \& R. Dirven (Eds.), Applied cognitive linguistics II: Language pedagogy (pp. 29-54). Berlin and New York: Mouton de Gruyter. https://doi.org/10.1515/9783110866254.29

Laufer, B., \& Eliasson, S. (1993). What causes avoidance in L2 learning: L1-L2 difference, L1-L2 similarity, or L2 complexity? Studies in Second Language Acquisition, 15, 35-48. https://doi.org/10.1017/S0272263100011657

Liao, Y., \& Fukuya, Y. (2004). Avoidance of Phrasal Verbs: the Case of Chinese Learners of English. Language Learning, 54(2), 193-226. https://doi.org/10.1111/j.1467-9922.2004.00254.x

Osborne, J. (2008). Adverb placement in post-intermediate learner English: A contrastive study of learner corpora. In G. Gilquin, S. Papp, \& M. B. Díez-Bedmar (Eds.), Linking up contrastive and learner corpus research (pp. 127-146). Amsterdam and Atlanta: Rodopi. https://doi.org/10.1163/9789401206204_006

Pütz, M. (2007). Cognitive linguistics and applied linguistics. In D. Geeraerts \& H. Cuyckens (Eds.), The Oxford handbook of cognitive linguistics (pp. 1139-1159). Oxford: Oxford University Press.

Sharma, S. (1980). Practical and Theoretical Consideration involved in Error Analysis. Indian Journal of Applied Linguistics, 6, 74-83. https://doi.org/10.11649/cs.2015.027

Siyanova, A., \& Schmitt, N. (2007). Native and non-native use of multi-word vs. one-word verbs. International Review of Applied Linguistics in Language Teaching (IRAL), 45(2), 119-139. https://doi.org/10.1515/IRAL.2007.005

Sroka, K. (1972). The Syntax of English Phrasal Verbs. Paris: Mouton. https://doi.org/10.1515/9783110801378

Wible, D. (2008). Multiword expressions and the digital turn. In F. Meunier \& S. Granger (Eds.), Phraseology in foreign language learning and teaching (pp. 163-181). Amsterdam and Philadelphia: John Benjamins Publishing Company. https://doi.org/10.1075/z.138.13wib

Yasuda, Y. (2012). Learning Phrasal Verbs Through Conceptual Metaphors: A Case of Japanese EFL Learners. TESOL Quarterly, 44(2), 250-273. https://doi.org/10.5054/tq.2010.219945

\section{Appendix A}

\begin{tabular}{ll}
\hline Phrasal Verbs with Contextual Support & Phrasal Verbs with Contextual Support \\
\hline $\begin{array}{l}\text { Luckily, the police officer let me off with a warning. } \\
\text { Most accidents on this motorway are caused by drivers who bomb }\end{array}$ & $\begin{array}{l}\text { Drink up and let's join them at the table. } \\
\text { along with no respect to speed limits and road safety. }\end{array}$ \\
$\begin{array}{l}\text { I have to get down to work straight away and submit the report today. } \\
\text { I would like to stop working for the firm I am working for at the }\end{array}$ I was afraid I'd end the evening having to wash up! \\
$\begin{array}{l}\text { moment and set up my own company. } \\
\begin{array}{l}\text { He tried to make up for missing her birthday party by getting her a } \\
\text { huge doll house but she was still angry at him. }\end{array}\end{array} \quad$ He just clammed up and pretended to be busy. \\
\hline
\end{tabular}


I can assure you that we will look into all of your complaints

I wouldn't have been surprised if she'd cracked up. thoroughly and get back to you by the end of the day.

Detective Smith was on his way to check a report of a possible break-in about which the police has been tipped off by an anonymous phone call.

Smith got out of the car to arrest the thief, but the man heard the noise of the car door, jumped to the ground and ran away.

You have to book weeks in advance to get into this restaurant!

After all, she's chalked up some happy relationships in the past.

Well, the décor is marvelous and I must say, from browsing through

the menu, the range of dishes they offer is most impressive, too.

\section{Copyrights}

Copyright for this article is retained by the author(s), with first publication rights granted to the journal.

This is an open-access article distributed under the terms and conditions of the Creative Commons Attribution license (http://creativecommons.org/licenses/by/4.0/). 